\title{
THE SUPREME COURT AND THE LAW OF OBLIGATIONS
}

\author{
G. H. L. FRIDMAN*
}

In this article, Professor Fridman criticizes the Supreme Court of Canada for what he feels to be its lack of independence of thought and reasoning in its tendency to apply English precedents rather than to develop its own opinions in the area of contracts, quasi-contracts and torts. He recommends that the Court should analyse problems in depth at every opportunity afforded to it so as to provide greater guidance for the lower Courts of Canada.

To ask someone to comment on the performance of the Supreme Court of Canada in the area of obligations is almost, though not quite, like giving a dog a virtually meatless bone on which to chew. The net result is to whet the appetite without providing any substance to satisfy what has been aroused. Or, if you prefer, salivation without salvation. If you are prepared for such frustration, stay and listen. In its way, the exercise is not without fascination. Nunc transeamus ad obligationes. Obligatio est juris vinculum quo necessitate adstringimur alicuius solvendae rei secundam nostra civitatis jura. ${ }^{1}$

As we all know, the members of what might be termed Justinian's Law Reform Commission, who were both more active and more successful than many such a body that has been initiated since, proceeded to divide obligations into four groups. Discarding one - the constituents of which have long since been absorbed elsewhere - we are left with three. It is with these, as they developed in the common law and as that development has been received and treated by the Supreme Court of Canada, that I am concerned; and, in particular, I am concerned with the creation of these obligations. In other words, with the circumstances under which the courts will create liability upon an obligation which arises ex contractu, quasi-ex contractu, or ex delicto.

Thus we are looking at the Supreme Court's attitude towards (i) the recognition of binding agreements between parties: (ii) the imposition of some liability to pay or restore money where there is no such agreement, but the law says there ought to be such liability: and (iii) the extent to which the commission of an act, or guilt of some omission, is wrongful and gives rise to a liability to compensate.

One point can be made at the outset. The Supreme Court has been even less innovative or original in the area of contractual obligations than it has been in respect of their creation by tortious conduct or in situations giving rise to a quasi-contractual relationship. Quite apart from what might be termed the innate conservatism of the court in its corporate sense and its surprising lack of individuals with the necessary qualities to produce revaluations of the old and insight into the new, - in both of which the Supreme Court of Canada compares most unfavourably with the High Court of Australia - or even, save the mark, the House of Lords, - there are other reasons which help to explain this difference. Thus, in contracts, the case law of the nineteeth century by and large settled many of the problems which had faced the common law. The classical period in the history of the English law of contract was from the time of Lord Mansfield to the time of Lords Blackburn and Bowen. Later judges such as Sumner, Scrutton and Atkin may have refined some of the doctrines: but the basic principles were established long before their day. Perhaps this was the consequence of the development of commerce and industry in England in those

- Professor of Law, University of Western Ontario.

1 Justinian, Institutes, III, 13, pr. 
decades. Social and economic causes required the settlement of the law governing commercial transactions whether on a large or small scale. Nothing in the history of Canada appears to have required a different outlook upon the law (at least until the twenties and later of the present century when some social problems in the prairies, for example, may have stirred judges in those provinces to take a different view in respect of certain kinds of transactions - and later to legislative intervention to protect some classes of society). ${ }^{2}$ Thus the Supreme Court was happy to follow the English precedents in such matters as notice of terms of a contract, offer and acceptance, capacity to contract, consideration, non est factum, part performance for the purposes of the Statute of Frauds and so on. What has happened, however, as will be seen, is that in more recent times, the English courts, notably the House of Lords and the Privy Council, have themselves been more innovative. The modern generation of senior English judges, Diplock, Simon, Salmon, Wilberforce (to say nothing of Denning - who is not only theoretically, but also in practice perennially youthful) have been prepared to re-interpret and, if need be, rewrite some of the classical propositions of the law of contract. With the result that some decisions of the Supreme Court of Canada now look very archaic, retrogressive, and, in a sense, indigestible. To this I shall return.

The second reason for the absence of innovation or originality in relation to contracts is that the problems that emerged out of certain situations were not startlingly different, if different at all, from those which had faced the English courts before or after 1875. Torts and quasi-contracts have presented new difficulties - indeed are still doing so: and the decisions of the past have not been completely useful in resolving the issues of today. While there may be an inertial tendency to rely upon established English decisions in these areas, this is not always as possible as in contract for two reasons: first, the decisions may not exist at all; secondly, even if they do, they may not be wholly applicable because the fact situations are not the same in all respects or the attitudes of the law are changed and should be changed. Thus, the English courts gave no guidance in regard to quasi-contracts, at least until the heretical judgments of Lord Wright in Brooks Wharf v. Goodman Bros. ${ }^{3}$ and the Fibrosa case, ${ }^{4}$ in which he repudiated what had in fact been decided by the House of Lords in Sinclair v. Brougham (which Canadian judges seem to have ignored, if they ever knew it existedl) And, for once, the rival attractions of the United States development appear to have overcome in some respects, the more natural charm of the common law in its old and original home.

With regard to torts, where the law was settled, the Supreme Court was content with what the English courts had decided by way of solutions to the problems. However, although this attitude is still adopted and can be seen practiced in very recent cases, two qualifications can be made. First: there have been instances of new problems requiring solution hitherto not faced by the English courts; secondly, there are some signs of independence to be found in judgments in the Supreme Court (even if the occasional judge of a provincial court, chooses to ignore the Supreme Court, and follow the House of Lords instead).

2 I refer here to developments in respect of sale of goods and the debtor-creditor relationship, especially in respect of farming activities.

8 [1937] 1 K.B. 534 .

4 [1943] A.C. 32.

[ [1914] A.C. 398. 
One final general point can perhaps be made before discussing the three areas of the law with greater particularity. It seems that in the past the jurisdiction of the Supreme Court has been such that it has been compelled to deal with and decide many cases which are almost entirely factual rather than to raise or suggest issues of legal principle. In addition, it has been abliged to deal with a large number of cases. Both factors make it difficult for a court of last instance of such importance to deal adequately with the broader issues of legal liability, both from the standpoint of time and content. Thus questions which ought to have been raised quite probably never were; and if they were, it may well have been totally out of the question for the court to approach and determine them with that degree of depth and analysis that was necessary and has been shown towards such issues by, for example, the House of Lords or the High Court of Australia. It may well be that in the future, with a revised jurisdiction, the Supreme Court will be able to achieve greater success through being afforded greater opportunity for success. That lies in the future. And what is in store is presaged by the recent decision in Veinot v. Kerr-Adison Mines Ltd. ${ }^{6}$ in which the Supreme Court gives a very full discussion of the issue of liability to trespassers. The detail and depth of analysis in that case would seem to indicate a change for the better from what has happened in the past - to which we must now turn.

The elements of a contractual obligation are the manifestation of an intent to contract by an offer and an acceptance, consideration and a valid consent. Time and again the Supreme Court has emulated the example of the English decisions, not only in respect of the broad general principle, but also with regard to details of the contractual process. Thus, the old English postal acceptance rule or doctrine that was first formulated in the early part of the nineteenth century (and has been criticised, even qualified, since then) was adopted by the Supreme Court in a Quebec case, no less, in which it was held that the civil law was the same as the English. No doubt civilians who read Magann v. Auger ${ }^{7}$ have disliked the equation and would prefer a more bicultural approach to such questions. Some qualification was permitted in Charlebois v. Baril, ${ }^{8}$ in which relief from the strict rule was given when the circumstances revealed that the post office was not, and was not intended to be, the authorized agent of the offeror. But the shifts required by that case exposed the inherent absurdities of the English doctrine, dating as it does from a period when the post was the main, if not the only method of transmitting communications - and an uncertain one at that. One can be less critical of the decision in Barrick v. Clarke ${ }^{9}$ that acceptance must be within a reasonable time, if no time limit has been fixed.

On the other hand, in Grand Trunk Pacific Coast S.S. Co. v. Simpson, ${ }^{10}$ the majority and the dissenting Chief Justice both followed English authorities ${ }^{11}$ different, of course, in each instance - to arrive at a solution of the classical problems of the contracting party who has not read all the terms, because they were contained on a ticket, and, naturally, people do not read tickets. (How many people today read the little print on their airline ticket? Or could have done

B (1975) 51 D.L.R. (3d) 533.

T (1902) 31 S.C.R. 186.

8 [1928] S.C.R. 88.

O [1950] 4 D.L.R. 529.

10 (1922) 63 S.C.R. 361.

11 Viz., Richardson, Spence \& Co. v. Rowntree [1894] A.C. 217; Hood v. Anchor Line [1918] A.C. 837; Cooke v. T. Wilson Sons \& Co. Ltd. (1915) 85 L.J.K.B. 888. 
anything about it if they had?). Here was an opportunity for the court to look at the realities of the problem and go beneath the technicalities of the doctrine of offer and acceptance as enunciated in England. Did it? Not at all. The judgments are a juggling of conflicting precedents in order to determine which course was right, or which ones sufficiently resembled the facts before the court to let them decide the issue.

In one case on the scope of offer and acceptance, however, there is a hint of something novel, an insinuation of a non-English approach, not entirely original, it must be admitted, but at least different. This is the case of Dawson v. Helicopter Exploration Co. Ltd.12. For the most part the members of the court simply analysed the facts on traditional lines in order to discover an offer and acceptance within the confines of the correspondence between the parties. But Rand J. (with whom Fauteux J. agreed) enunciated a doctrine of looking for something which is "instinct with an obligation". This he derived from a judgment of Cardozo J. while still in the New York Court of Appeals. At least it was a constructive attempt to get away from stilted classical formulae and provide a new basis upon which courts could determine whether there was indeed a contract between the parties. This might have provided the basis for the later decision in Saint John Tug Boat Co. Ltd. v. Irving Refinery Ltd. ${ }^{13}$ in which, again, the court had to decide whether there was a binding contract between the parties as a result of their conduct - in the absence of the traditional stipulatio situation of such cases, whether English or Canadian. Instead the court proceeded to decide the case by following the perplexing, nay confusing English decision in Smith v. Hughes ${ }^{14}$ (which is really all about something else) so as to hold that silence amounts to consent, if it is "positive" enough. Here was an opportunity lost - to develop a new concept of contractual obligation, to move away from the classical mould, so irrelevant to modern fact-situations, which do not always lend themselves easily to being resolved by reference to the old models. The Supreme Court preferred to be Procrustes rather than Pygmalion.

The doctrine of consideration, which has frequently been under attack in recent years, is another area where the Supreme Court has contented itself with the repetition of English doctrine. Indeed, in regard to the subject of charitable subscriptions, which have more than once been before the court, once in a Quebec case in which again the court assimilated the common and civil law, ${ }^{15}$ the court rejected the more liberal American view that had been propounded by inter alia, Cardozo J., and came down firmly in favour of the strict English approach, ${ }^{16}$ in consequence of which charitable donors could evade responsibility for earlier promises of munificence. In Dalhousie College v. Boutilier Estate ${ }^{17}$ the Supreme Court wrote finis to any attempt to undermine the technical doctrine of consideration in the interests of charity. Nor were they prepared to outflank the doctrine by a more liberal use of the notion of quasi or equitable or promissory estoppel, whether in charitable subscription cases or elsewhere. Despite the interesting development in England in the High Trees Case, ${ }^{18}$ and the path that had been opened up, a trifle more clearly by Lord Denning, since the

12 [1955] S.C.R. 868.

13 [1964] S.C.R. 614.

14 (1871) L.R. 6 Q.B. 597.

15 Re Ross [1932] S.C.R. 57.

${ }^{16}$ Re Hudson (1885) 33 W.R. 819; Re Covey (1912) 29 T.L.R. 18.

17 [1934] S.C.R. 642.

18 [1947] K.B. 130. 
Dalhousie College case and others of the thirties, ${ }^{19}$ the Court in Conwest Exploration Co. Ltd. v. Letain ${ }^{20}$ in 1964 stated, through the mouth of Judson, J. in the majority and Martland J. in dissent that the High Trees principle was an equitable defence only: it could not form the basis of an action. Admittedly, this is consistent with the English authorities from the nineteenth century to recent years. Law has not stood still elsewhere however: but the Supreme Court of Canada has not been willing to listen to, and $a$ fortiori to adopt, any different approach.

So plagiaristic has been the court that it has been left "holding the baby" as it were, more than once. Foot v. Rawlings ${ }^{21}$ is a good example. There it was held that giving a creditor a post-dated cheque was good consideration for the creditor's promise not to sue on the original contract. In other words, this was an exception to the doctrine of Pinnel's case ${ }^{22}$ as repeated in Foakes v. Beer ${ }^{23}$ by the House of Lords. Of course, statute has made changes in many Canadian provinces but it still seems that the possibility of such an issue can arise. In the Foot case in 1963, the court followed the old English decision in Sibree v. Tripp. ${ }^{24}$ A few years later, in D.C. Builders v. Rees, ${ }^{25}$ the English Court of Appeal said that the whole idea in Sibree v. Tripp was bad. Giving a post-dated cheque could not constitute an accord and satisfaction: there was no consideration. The arguments accepted by the English court could have prevailed with the Canadian, but they did not. Technique overcame reason.

The same situation has more recently arisen in respect of the doctrine of non est factum. In Prudential Trust Co. v. Cugnet ${ }^{26}$ in 1956, at a time when the problem was coming up before Canadian courts and the Supreme Court especially, in case after case, mainly from the Prairies, because of the oil leases and the vast royalties and benefits that were involved, the Court followed Carlisle \& Cumberland Banking Co. v. Bragg, ${ }^{27}$ a 1911 English Court of Appeal case, to hold that negligence in signing a document did not defeat the plea of non est factum unless there was a duty of care owed by the signer, which probably limited this to cases involving negotiable instruments. They were caught with their pants downl The House of Lords in Gallie v. Lee ${ }^{28}$ turned the law upside down.

This has also been done in England by statute with respect to the effect of innocent misrepresentation upon a contract..$^{20}$ In Redican v. Nesbitt, ${ }^{30}$ it would seem, (though this is not entirely clear, as the case was one of fraud) that the Supreme Court adopted the English decisions in Angel v. Jay ${ }^{31}$ and Seddon v. N.E. Salt $\mathrm{Co}^{32}$ to hold that once a contract was executed, it was too late to

10 See e.g. Fridman, Promissory Estoppel (1957) 35 Can. Bar Rev. 279; Fridman, The Basis of Contractual Obligation (1974) 7 Loyola of Los Angeles L.R. 1.

20 [1964] S.C.R. 20.

21 [1963] S.C.R. 197.

22 (1605) 5 Rep. 117a.

23 (1884) 9 A.C. 605.

24 (1846) 15 M. \& W. 23.

25 [1966] 2 Q.B. 617.

${ }^{28}$ [1956] S.C.R. 914.

27 [1911] 1 K.B. 489.

28 [1971] A.C. 1004.

29 Misrepresentation Act 1967.

30 [1924] S.C.R. 135.

31 [1911] 1 K.B. 666.

32 [1905] 1 Ch. 326. 
obtain a remedy for innocent misrepresentation. If this is indeed the result of that case, it requires re-investigation. It was bad law at the time: even probably before then, at the time the point was dealt with in the English cases. More recent developments (in England and Canada) ${ }^{38}$ have made it worse law. The Supreme Court ought to have rejected the English view in 1924. Since it did not, it should certainly do so at the earliest opportunity.

One point becomes very clear from this brief account. It is useless for the Court to attempt to follow the traditional English law of contract and in particular decided cases on an individual basis. English law is going through a period of change, some of it at the hands of the judges. There is the danger (which has already become manifest and has produced catastrophe) that the hitherto solid rock of precedent will become shifting sands, - if I may be permitted that very mixed metaphor! With the result that Canadian law will be well behind the common law elswhere.

This, I am happy to state, has not been so with respect to obligations implied by law, quasi-contracts, if you like, or the doctrine of unjust enrichment or restitution, if you prefer something even more different by way of nomenclature. Whatever it be called, this area of the law, for reasons already suggested, has been the subject of some development - "considerable" might be too positive and emphatic a term - some development at the hands of the Supreme Court.

Who, after all, has not heard of the Deglman case?34 It must rank as a twentieth century classic in any country. At one and the same time it provided a summing-up of the old law on quasi-contract, or, if you like, a peroration to the era of Sinclair v. Brougham, ${ }^{85}$ and a starting point of new growth in this area of the law. From its womb, as it were, there have been subsequent examples of recovery on a non-contractual basis: i.e. where the situation deserved that some recompense be given to one who had performed services for another. ${ }^{86}$ An entirely new arena of argument was opened up for counsl who could not rely on a contract by reason of some obstruction such as the Statute of Frauds. No doubt the court did not think that it was doing, or intended to do anything novel by its decision or the reason which underlay it. Clearly the language of the court was based upon earlier dicta and precedents from England. But the real effects have been much more innovative than the court probably desired. Side by side with this development, which may one day lead to a more general doctrine of negotiorum gestio - "may", I said, not necessarily will, (though it is not beyond the bounds of possibility or the limits of desirability) - there have been others in the same broad area of obligations.

Several years before Deglman, the Court in Knutson v. Brookes ${ }^{37}$ held that recovery on the basis of compulsion was possible not only where the party paying under duress had done so to avoid losing property, but also where he had done so to avoid being deprived of the "hope of property". The rights, proprietary or otherwise, interfered with by the compulsion were not in fact vested rights (as in other English and Canadian cases), but were contingent ones. It was enough. This opens up another potential source of obligation in the absence of contract, as does the post-Deglman case of Eadie v. Township of Brantford. ${ }^{38}$

\footnotetext{
83 Particularly with respect to contracts covering sale of goods.

84 Deglman v. Guaranty Trust Co. of Canada [1954] 3 D.L.R. 785.

85 [1914] A.C. 398.

86 There have been several decisions since then, in the Supreme Court of Canada and in provincial Supreme Courts.

87 [1941] 3 D.L.R. 593.

88 (1967) 63 D.L.R. (2d) 561.
} 
In that case, the court held that in a claim for repayment on the basis of compulsion it was not necessary for the plaintiff to establish that he lacked any alternative but to pay at the time of the original payment. It sufficed if any other course of action was impracticable and therefore impossible, by reason of delay or the expenditure involved. Add these cases together, and mix in a dash of illegality as evidenced in George (Porky) Jacobs Enterprises Ltd. v. City of Regina $a^{39}$ and you have a very effervescent, even explosive, concoction that is capable of blasting new trails in the realm of quasi-contractual recovery, or, if you prefer, obligations arising out of one person's unjust enrichment at the expense of another.

Yet in other cases, in which actual or potential quasi-contractual recovery was in issue, the court has been much more restrained. It has decided the case by the use of early English precedents, as in County of Carleton v. City of Ottawa, ${ }^{40}$ which could have been the source of a general doctrine of quasi-contractual obligation, but was treated as a straightforward case of compulsorily discharging another's liability d la Brooks Wharf v. Goodman Bros. Or it has not proceeded on such basis at all, preferring to find another, more traditional ground for granting relief such as frustration in the Peter Kiewit case, ${ }^{41}$ or copyright in Webb \& Knapp v. the City of Edmonton. ${ }^{22}$ Opportunities have been lost. Chances to bring together all the different strands of this novel area of obligation have been allowed to slip through the hands of the court. Why? Is it judicial ignorance? Hardly! That would be strange in view of the way the Supreme Court and other Canadian courts have utilised the inspiring and seminal speech of Lord Wright in the Fibrosa case. Is it then a lack of what Sir Frederick Pollock once termed judicial valour? Possibly. What is needed is a Hercules on the Bench to cleanse the Augean stables of the English law of quasi-contract from the encrustations of the centuries and make the whole area shine with the brilliance of its underlying ideas.

I come now to the subject of torts - the most fascinating of all topics of law. The true aficionado views a tort problem like a bullfight: it aftords the spectacle of man's ingenuity, skill and nerve pitted against the clumsy energy of the facts. Can the daring of the Bench overcome the brute force of circumstances in order to achieve not only a solution, i.e. the death of the bull, but a solution that is harmonious, logical and elegant, i.e. a clean, neat and beautiful kill.

Sadly, it must be related that the Supreme Court has not always acquitted itself well in this arena. Indeed it might be said that what has been lacking has been machismo. Typifying this is the recent decision of the court in the Rivtow case. ${ }^{43}$ Here was an opportunity for the Court to come down firmly on the side of wider liability for economic loss, taking the law a stage further than the English courts had done under Donoghue v. Stevenson,"4 in relation to negligence liability for physical damage or injury, and Hedley Byrne v. Heller's in relation to the infliction of financial damage. The majority of the Court, over the dissent of Laskin and Hall JJ., took the narrow view. In that case, it will be remembered,

89 (1964) 44 D.L.R. (2d) 179.

10 (1966) 52 D.L.R. (2d) 220.

41 Peter Kiewit Sons v. Eakins (1960) 22 D.L.R. (2d) 465.

12 (1970) 11 D.L.R. (3d) 544.

13 Rivtow Marine Ltd. v. Washington Iron Works (1974) 40 D.L.R. (3d) 530.

4 [1932] A.C. 562 .

45 [1963] 2 All E.R. 575. 
the claim was for the loss of purchasers of a crane in the form of the cost of repairs and the loss of revenue for inability to use the crane because it was defective. The Court ultimately held that the loss of revenue was recoverable but not the cost of the repairs. Yet it seems hard to differentiate the two classes of damage which flowed from the same tort, whether that tort was negligent manufacture of goods or negligent failure to warn of the defective nature of the goods. The attitude of the majority of the court seems unduly and even unnecessarily restrictive.

In the same way, in other decisions, the Court adopted a restrained and restrictive view of the Hedley Byrne doctrine, preferring the majority opinion of the Privy Council in the Evatt case ${ }^{40}$ to the better views, i.e. better in the opinion of the present writer (and many others it may be added), which had been expressed by the minority in the Evatt case. The opinion that theirs was the better view is strengthened by the fact that the minority in the Evatt case consisted of two members of the House of Lords ${ }^{47}$ who had sat on the Hedley Byrne decision. Presumably they knew what they had meant in 1963-even if no one else did or could! But the decisions of the Supreme Court of Canada in the Welbridge and Nunes Diamonds cases have helped to perpetuate a narrow range of activity for the very broad, remedial and innovative principle that was introduced into the law of torts in 1963. In the Welbridge case ${ }^{48}$ the court refused to permit liability for a negligent representation as to zoning permission which caused loss to a company that was formed in consequence of the representation to develop a piece of land in Winnipeg. This was largely on the ground that the municipality which was charged with the tort was merely negligent in the performance of its statutory powers: it was not fraudulent or deliberately and intentionally wrongful. The law of negligent misrepresentation, such as it was, did not reach out to cover the case of a legislative or other statutory tribunal with quasi-judicial powers which, in good faith, made a decision that later turns out to be invalid. In the Nunes Diamonds case ${ }^{40}$ liability was denied for an alleged negligent misrepresentation which supposedly led to the burglary of the plaintiff's premises, on the ground that the relationship between the parties was governed by a contract which excluded or limited liability: hence there was no room for the imposition of any relationship arising ex delictu. In deciding this case as it did the court accepted and supported the sharp dichotomy between obligations arising from tort and those arising from contract-their mutual exclusivity and inability to co-exist and operate together which, it may be thought, continues into effect an increasingly more outmoded approach to obligations and liabilities, stemming as it does from the post-mediaeval developments of the writ system which have been criticised, and even repudiated in other contexts, such as the trespass/negligence area. ${ }^{50}$ One cannot help but feel that in respect of liability for negligent misrepresentation the Court has not been aware of the possibilities: or if aware has been unwilling, even frightened to give full rein to the horse. It could be that, if that were done, the animal might take off and carry their Lordships to some new and unexplored territory: but I, for one, cannot accept that the members of the Court would be totally unable to control matters and direct the journey to whatever terminus ad quem they desired. The

${ }^{46}$ Mutual Life \& Citizens Assurance Co. Ltd. v. Evatt [1971] I All E.R. 150.

17 Lords Reid \& Morris.

18 Welbridge Holdings Ltd. v. Metropolitan Corporation of Greater Winnipeg (1972) 22 D.L.R. (3d) 470.

49 J. Nunes Diamonds Ltd. v. Dominion Electric Petroleum Co. (1972) 26 D.L.R. (3d) 699. Cf. the attitude of Lawson J. in Esso Petroleum Co. Ltd. v. Mardon [1975] 1 All E.R. 203.

${ }^{50}$ See, e.g. Letang v. Cooper [1965] 1 Q.B. 232. 
attitude in the 1970's seems no more advanced than it was in the 1950's when the Court had before it the famous case of Guay v. Sun Publishing Co. ${ }^{51}$ There, it will be recalled, the various members of the court (except for Rinfret C.J. and Cartright J. - all honour and glory to them for being willing to assimilate nervous, shock to physical injury and permit recovery for a negligent misstatement which caused the former just as they would have been had it caused the latter) gave different reasons for denying Mrs. Guay an action in negligence when she was upset by the untrue report of her husband's death. There was no duty of care since she was not a neighbour. There was no physical injury. There was no duty of care in respect of statements. Tot homines, quot sententies.

Have we come much further since then? On the subject of nervous shock we do not know what the Supreme Court now thinks. Hopefully one day they will have the chance to speak ex cathedra and put to rights some of the more unfortunate decisions of provincial Supreme Courts. On negligence generally we have more idea of their views, thanks to several recent cases on products liability and liability to rescuers. They seem to be coming round to a more flexible and tolerant view from the standpoint of plaintiffs. In Lambert v. Lastoplex Chemicals Co. ${ }^{32}$ the Court was prepared to extend the scope of the manufacturer's duty. In the Ogopogo $I I^{53}$ and the Slobodian cases $^{54}$ they were ready and willing to support the concept of a duty which could be owed to those who attempt to rescue others - whether the one to be rescued was potentially capable of rescue, as in the ship case, or probably beyond the reach of rescue, as in the lorry case. Similarly in the Veinot case ${ }^{55}$ the majority of the court appears to have taken a more relaxed and liberal attitude towards liability for injuries caused to trespassers following the example of the House of Lords and the Privy Council in the Herrington ${ }^{56}$ and Cooper ${ }^{57}$ cases.

There are many other areas of tort law, and many other cases, a goodly number of which have been the subject of fairly recent discussion by $\mathrm{Mr}$. Weiler in the University of Toronto Law Journal. ${ }^{58}$ I do not propose to consider these in detail here. I am concerned with matters he did not mention.

Thus, in relation to one of the more important disputes of modern times in the law of tort, that between the strict liability approach of Re Polemis ${ }^{50}$ and the more flexible notion expounded by the Privy Council in The Wagon Mound (No. 1), ${ }^{80}$ as to remoteness of damage in negligence cases, we find that the Court has not yet stated firmly enough its position. There are hints to be found from time to time. ${ }^{01}$ But so far no case has ever turned decisively on the point in question. Until the Court has spoken, therefore, it may be too soon to express what will be the Canadian view on this controversy. We have heard shouts from

s1 [1953] 2 S.C.R. 216.

32 (1971) 25 D.L.R. (3d) 121.

s3 Horsley v. MacLaren [1972] S.C.R. 441.

s4 Carothers v. Slobodian (1975) 51 D.L.R. (3d) 1.

ss Supra, n. 6.

so British Railways Board v. Herrington [1972] A.C. 877.

s7 Southern Portland Cement Ltd. v. Cooper [1974] 1 A11 E.R. 87.

${ }^{58}$ Weiler, Groping Towards a Canadian Tort Law: The Role of the Supreme Court of Canada (1971) 21 U. of T. L.J. 267.

59 [1921] 3 K.B. 560.

${ }^{60}$ [1961] A.C. 388.

o1 E.g. per Laskin J. in the Wellbridge case, supra n. 48. 
the sidelines to the effect that foreseeability is not the answer. ${ }^{62}$ From the players there has been comparative silence.

Likewise the Court has been ambiguous, even obfuscatory on the subject of causation and proof of negligence. If one compares the decision in Cook v. Lewis, ${ }^{03}$ ostensibly a trespass case, though recent English authority would turn such trespasses into negligence, with the later decision in Wotta v. Haliburton Oil Well Co., ${ }^{64}$ which was unquestionably a negligence case, one gets the impression of some ambivalence on the issue of who is liable when there are two potential tort-feasors and the facts do not clearly point to one rather than the other as being the source of the plaintiff's injury. Yet, when issues of liability are involved, it is crucial for the Court to know how to proceed in instances of actual or potential multiple defendants.

In much the same way the Court has manifested many tergivisations, twists, and divergencies on the subject of the plaintiff who is, or who is alleged to be volens. If one contrasts the cases of Car \& General Insurance Corp. Ltd. v. Seymour \& Maloney, ${ }^{65}$ Miller v. Decker, ${ }^{68}$ Lehnert v. Stein ${ }^{67}$ and Eid v. Dumas, ${ }^{68}$ in which subtle changes of fact produced different decisions in law, one comes away with the idea that the Court has not as yet produced a firm policy on the subject of how to deal with the plaintiff who is alleged to have accepted the risk of being injured by the defendant's negligent conduct, especially the negligent driver of a motor vehicle. Mr. Weiler, in his discussion of this area, comments of the behaviour of the Court that "it is simply not good enough for the highest appellate court in the land ${ }^{\prime \prime} .{ }^{69} \mathrm{He}$ was, and is still quite right.

But the same sort of behaviour is visible in other contexts. For instance, the Court has frequently avoided the real issues in defamation cases. Take the recent decision in Fraser v. Sykes. ${ }^{70}$ Many vital problems in the law of defamation were raised in the course of that litigation. Some of them were dealt with by Lieberman J. of the Supreme Court of Alberta at the trial. One was the question of qualified privilege. Another was the allied problem of malice in such cases. They were not dealt with by the Supreme Court. Instead we find a detailed analysis of the facts in order to arrive at a conclusion on the question whether there was or was not a defamatory statement made of the plaintiff by the defendant. If you want to know more about malice and qualified privilege you have to read the recent House of Lords decision in Lowe v. Horrocks. ${ }^{71}$

Another issue which arose in Fraser v. Sykes was the question of punitive damages. The Supreme Court has obliquely repudiated the English position on such damages (in a dissenting judgment, no less), but with such lack of strength, definition, and conviction that the Chief Justice of Nova Scotia was able, quite

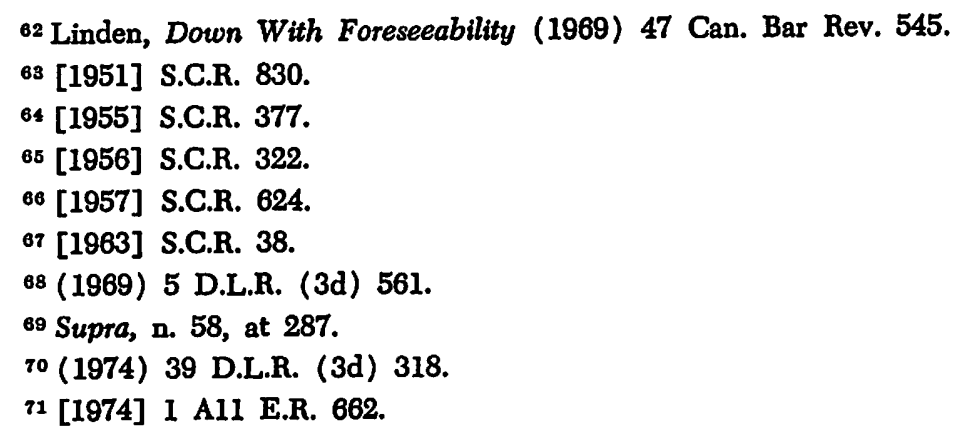


recently, ${ }^{72}$ to adopt the reasoning of the House of Lords in Cassell v. Broome ${ }^{73}$ despite what has been said by the Court in the Cooper-Smith case ${ }^{74}$ (and incidentally by me in the Canadian Bar Review). ${ }^{75}$

One decision does stand out as being original, and as providing evidence of a revolt from the slavish bondage to English precedents that is too frequently manifested in decisions of the Court. This is the case of Fleming v. Atkinson. ${ }^{i 0}$ In that case the Supreme Court did not accept the English doctrine ${ }^{77}$ that there was no duty to keep horses fenced so as not to injure users of the highway. For once their Lordships agreed that what was proper and justifiable in England in the light of English social history and development was not appropriate to the Canadian scene. But this is virtually the sole instance of a similar independence of thought and reasoning that has been characteristic of the High Court of Australia throughout its much shorter life as the highest appellate court in a country with a system of law that emerged from the common law of England. For the most part the Canadian record is dreary. The history of the court in relation to torts, and the judgments in tort cases are, in Hamlet's words, "weary, stale, flat and unprofitable."

Something, therefore, must be done. If not, future generations of law students in this country will grow up, in the way their forbears have, with the impression that the Supreme Court is composed of a set of fuddieduddies - if that word is Parliamentary language - who have not an original idea in their individual or collective heads, and simply reach for the nearest precedent when a case comes before them. There are many problems in tort, as in contract and restitution, which will reveal themselves in the future and require bold, imaginative and, above all, definite resolution by the courts, and in particular by the Supreme Court of Canada, which must set the tone for courts below it and map out the paths by which judges of those courts can arrive at proper and acceptable solutions to the litigation that they are appointed to try and determine. What I would suggest, with the greatest of respect, is that the Court, at every opportunity that is afforded to it, attempt to analyse in depth and in full the true nature of the problem, its ramifications and its complexities, so as to put itself in the position of being able to speak with authority and resolution in a way which will guide other judges towards the right approach to the factual issues which present themselves from day to day. This is a difficult, time-consuming, and intellectually exhausting task. But it must be faced and undertaken if the law of obligations in Canada is to be placed upon a firm, decisive footing, capable of enabling society to cope with the problems of the latter part of the twentieth century and the not-too-distant years of the twenty-first. I am confident that the Court can do this. I can only hope that it will.

72 Banks v. Campbell (1974) 45 D.L.R. (3d) 603.

78 [1972] 1 All E.R. 801.

74 McElroy v. Cooper-Smith (1967) 62 D.L.R. (2d) 65.

${ }^{75}$ Fridman, Punitive Damages in Tort (1970) 48 Can. Bar Rev. 373.

78 [1959] S.C.R. 573.

77 Since changed by statute. 